\title{
Effect of Trading Volume on Market Returns of Equity Securities
}

\section{Market in Kenya}

\author{
Mwiti Jedidah Karwitha, Willy Muturi, Oluoch J. Oluoch
}

School of Business, Jomo Kenyatta University of Agriculture and Technology P.O Box 6200000200 Nairobi, Kenya

\section{ABSTRACT}

The study aimed to establish the effect of trading volume on market returns of securities traded in Kenyan securities exchange market. The study used secondary data from all the firms listed in NSE during the period 2004 to 2016 . The target population of the study consisted of the sixty four companies listed in Nairobi securities exchange market that is, both financial and non-financial companies. The study was a census study of all the sixty four companies listed in the Nairobi security exchange market for 13 years starting the year 2004 to the year 2016. The study started with descriptive and then diagnostic tests. The measures of central tendency used to test normality were mean, median, maximum and minimum value, standard deviation, skewness and kurtosis.The study further sought to investigate the stationality properties of market returns, trading volume. The study used five panel data unit root tests. Particularly the test were, Levin, Lin and Chu t, Breitung t-stat, Im, Pesaran and Shin W-stat developed, Fisher-type tests using augmented dickey fuller ADF and (Phillip and Peron) PP tests. These tests revealed that the variables were stationary on average. The cointegration results showed that there was long-run equilibrium. The regression techniques used was Cross-section fixed and Period fixed. The regression results revealed that the trading volume variable had a statistically significant effect on market returns. Study found that trading volume had a positive effect on the market returns. It is therefore in this light that the future research should consider other variables which would increase the predictive power of the model. The other relevant variables would be variables such as the size of the firm, market value of the firm and the macroeconomic variables such as exchange rate, inflation, money supply among others.

Keywords: Trading Volume, Market returns, unit root and cointegration
${ }^{*}$ Correspondence to Author:

Mwiti Jedidah Karwitha

School of Business, Jomo Kenyatta University of Agriculture and Technology P.O Box 62000-00200 Nairobi, Kenya.

How to cite this article:

Mwiti Jedidah Karwitha, Willy Muturi, Oluoch J. Oluoch. Effect of Trading Volume on Market Returns of Equity Securities Market in Kenya. Global journal of Economics and Business Administration, 2018,3: 12.

\section{eScîPub}

eSciPub LLC, Houston, TX USA. Website: http://escipub.com/ 


\subsection{Introduction}

Despite the Kenyan government effort on the development of the Nairobi securities exchange market, the market returns of the market has been volatile. According to Ngugi and Njiru (2005) there has been stagnation in the development of NSE with regard to the number of listing bearing in mind that the Kenyan market has been in existence for the last 62 years. Research on the significance of the market structure has been the subject of considerable interest in microstructure analysis. As indicated by Easley and O'Hara (2003), the behavior of prices and even the capability of markets depend on the ability of the trading structures to match the trading desires of the buyers and sellers. Hui-Ching (2014), investigates the contemporaneous and causal relations between stock returns, trading volume and volatility in a domestic market context and between different national markets for listed real estate companies in seven Asian economies. The study find that there are positive contemporaneous relations between trading volume and both returns and absolute returns. The study also examines the causal relations between the financial variables, the evidence implies that current trading volume helps to explain the returns indirectly by leading return volatility; however, trading volume does not help to explain future returns directly. This research provides global investors with a better understanding of the Asian listed real estate market, showing that trading volume contains important information regarding returns, that the characteristics of listed real estate companies are closer to those of the financial market than those of the real estate markets, and that the markets of the major economies have extensive influence over the smaller markets.

Abdullahi, Kouhy, and Muhammad (2014), set to examine the relationship between trading volume and returns in the West Texas Intermediate (WTI) and Brent crude oil futures markets. The study used daily closing futures price and their corresponding trading volumes for WTI and Brent crude oil markets during the sample period January 2008 to May 2011. Both the log volume and the unexpected component of the detrended volume are used in the analysis in other to have robust alternative conclusion. The generalized method of moments (GMM) approach is used to examine the contemporaneous relationship between returns and trading volume while the Granger causality approach, impulse response and variance decomposition analysis are used to investigate the ability of trading volume to predict returns in the oil futures markets. The results reject the postulation of a positive relationship between trading volume and returns, suggesting that trading volume and returns are not driven by the same information flow which contradicts the mixture of distribution hypothesis in all markets. The results also show that neither trading volume nor returns have the power to predict the other and therefore contradicting the sequential arrival hypothesis and noise trader model in all markets.

Girard and Omran, (2009), set to examine the change in speed of dissemination of order flow information on stock volatility of return in 79 traded companies at the Cairo and Alexandria Stock Exchange (CASE). The paper examines the interaction of volatility and volume in 79 traded companies in CASE over a period from January 1998 to May 2005 and provides support for the TGARCH specification for explaining the daily time dependence on the rate of information arrival to the market for stocks traded on CASE. The study found that information size and direction had a negligible effect on conditional volatility and, as a result, the presence of noise trading and speculative bubbles was suspected. It was found that the persistence in volatility is not eliminated when lagged or contemporaneous trading volume is incorporated into a GARCH model. It is shown that, when volume is further broken down into its expected and unexpected components, volatility persistence decreases. This is especially true after May 2001, which marks the beginning of a succession of major stock market reforms. It was 
also found that anticipated information shocks can have a negative impact on the volatility of return, particularly prior to May 2001. The decrease in the negative relationship between expected volume and volatility after May 2001 suggests that trading efficiency and information dissemination have improved. This is an important finding for CASE as it encourages the reform momentum and reinsures foreign investors.

Faff and McKenzie (2007), empirically assessed the determinants of conditional stock index autocorrelation with particular emphasis on the impact of return volatility that are theoretically linked through the behaviour of feedback traders. The S\&P 100, 500 and the NASDAQ 100 index are considered and volatility in each series is captured using option-implied estimates taken from the Chicago Board Options Exchange. A seemingly unrelated regression approach is used in which trading volume and volatility are simultaneously modelled. The results of this study suggest that low or even negative return autocorrelations are more likely in situations where: return volatility is high; price falls by a large amount; traded stock volumes are high; and the economy is in a recessionary phase. The results confirm that previous related work showing a link between autocorrelation and volatility is not induced by a mechanical relation. Usage of endogenously determined volatility measures in this area of the literature is justified. This study provides a robustness test of the autocorrelation/volatility relation, as well as a further exploration of the utility inherent in optionimplied volatility.

\subsection{Statement of the problem}

Despite the Kenyan government effort on the development of the Nairobi securities exchange market, the market returns of the market has been volatile. Statistical evidence shows that between the years 2000 to 2009 there were only 62 companies that were listed and 12 companies were delisted in the same period, between 2010 to 2016 only 62 companies were listed with 14 companies delisted in that period (NSE, 2016).
Also, according to Ngugi and Njiru (2005) there has been stagnation in the development of NSE with regard to the number of listing bearing in mind that the Kenyan market has been in existence for the last 62 years. Research on the significance of the market structure has been the subject of considerable interest in microstructure analysis. As indicated by Easley and O'Hara (2003), the behavior of prices and even the capability of markets depend on the ability of the trading structures to match the trading desires of the buyers and sellers.

Many Kenyan investors have been expecting an exceptional market returns from the Nairobi securities exchange market but this has not been the case. This is because the market has been experiencing weak management has evidenced by the collapse of two stock brokers in the years 2008 and 2009 which affected the investors' confidence. This also caused under subscription of both initial public offer and right issue for companies such as Kenya airways, Cooperative bank of Kenya and British American Insurance. This is a clear evidence that there has been a decline in the market returns of the exchange market. Akileng, Ogwang, \& Ssendyona, (2018) investigated the Determinants of market returns of securities exchanges in East Africa. The results showed that the trading volume had a negative effect on markets returns. Chae and Wang (2003) in United states found that trading activities had a negative effect on the market returns of equity securities market. Kelley, and Tetlock (2013) revealed that, the aggressive and passive net buying positively predict firms' monthly stock returns with no evidence of return reversal. Tapa and Hussin (2016), conducted a regression analysis in Malaysian Market using OLS method. The study concluded that there is a strong significant positive contemporaneous relationship between stock return and trading volume. Yonis (2014), examine the causal relations among trading volume and returns between the US and Tiger economies stock markets. The study found a positive 
contemporaneous relationship between absolute return and trading volume in the New York and Tiger Economies stock markets using OLS and GMM estimator.

Given the foregoing background, the study provides a four-fold problem with respect to how market microstructure dynamics affects equity market returns. It is not clear how trading volume, in the developing markets affects market returns of such markets as Nairobi securities market. Therefore this study aims at filling the knowledge gap existing by enlightening individuals and mostly potential investors about the existence of the market dynamics and their consequent effects on the market returns of the listed companies in the Nairobi Securities exchange market.

\subsection{Specific Objectives}

To determine the effect of trading volume on market returns of equity securities market in Kenya

\subsection{Research Hypotheses}

Trading volume has no significant effect on market returns of equity securities market in Kenya.

\subsection{THEORETICAL REVIEW}

\subsection{Trading Volume Theory}

Karpoff (1986), develops a theory of trading volume based on assumptions that market agents frequently revise their demand prices and randomly encounter potential trading partners. The theory describes two distinct ways informational events affect trading volume. One is consistent with conjectures made by empirical researchers that investor disagreement leads to increased trading. But the observation of abnormal trading volume does not necessarily imply disagreement, and volume can increase even if investors interpret the information identically, if they also have had divergent prior expectations. Simulation tests support the model and are used to contrast the random-pairing environment with costless market clearing. Volume is lower in the costly market, and volume increases caused by an informational event persist after the event period. This is consistent with existing empirical evidence and suggests that markets do not immediately clear all orders or that investors have demands to recontract.

Sanjay Sehgal, Vibhuti and Vasishth, (2015), set to assess the relationship between Past price changes, trading volume and prediction of portfolio returns in Brazil, India, South Africa, South Korea, Indonesia and China. Price momentum patterns were observed for Brazil, India, South Africa and South Korea, while there were reversals in Indonesia and China. Lowvolume stocks outperform high-volume stocks for all sample countries except China. The past price and volume patterns in stock returns were not fully explained by CAPM as well as the Fama-French Model. Price and volume momentum factors were found to play a role in explaining some of these return patterns. Finally, the unexplained returns seemed to be an outcome of investor under or overreaction to past information. The sources of price and volume momentum seemed to be partly risk based and partly behavioral.

\subsubsection{Market Efficiency Hypothesis}

Market efficiency hypothesis suggests that a market is rational and provides correct pricing. That is, the current prices of securities are close to their fundamental values because of either the rational investors or the arbitragers buy and sell action of under-priced or overstocked priced stocks. On the other hand, observed market anomalies have a challenge for this argument (Lim and Brooks, 2011; Yen and Lee, 2008) presented a landmark paper on the efficient market, which focused on comprehensive review of the theory and beyond the theory to empirical work. He defines market efficiency very clearly as a market in which prices always fully reflect all available information. Pagano distinguished three nested information sets: past prices, publicly available information and all the information including private information.

Efficient market hypothesis is divided into three stages as the weak form, semi-strong form, and the strong form with respect to the availability of 
the above-mentioned three information sets. Weak form of efficiency claims that the current stocks prices already reflect all historical market data such as the past prices and trading volumes (Christie, 1994). The assertion of weak form of efficiency is very much consistent with the findings of researches on random walk hypothesis; that is, the price changes from one time to another are independent .Semi strong form of efficiency expresses that, notwithstanding the past costs, all freely accessible data including key information on the company's product offering, profit estimate, profit, stock parts declarations, nature of administration, asset report creation, and licenses held, bookkeeping hones and so on ought to be completely reflected in security prices. Along these lines, one can't make unrivaled benefit by utilizing the basic investigation as a part of the business sector, which is productive in the semi-solid structure. Solid type of proficiency expresses that business sector costs mirror all data including the past costs and all openly accessible data in addition to all private data. In such a business sector, costs would dependably be reasonable and any financial specialist, significantly consider dealers can't beat the market (Fama, 1970)

The entire study revolves around market efficiency and therefore market efficiency theory is very useful in this study. The market returns of any securities exchange market entirely depends on how the kind of information that is available in the market and whether the prices of the securities reflect the available information in the market.

\subsection{Empirical Literature Review}

\subsubsection{Trading Volume and market returns}

Tapa and Hussin (2016) investigated the Relationship between Stock Return and Trading Volume in Malaysian ACE Market. The purpose of conducting the regression analysis using OLS method was to test the contemporaneous as well as the lagged relationship between stock return (volatility) and trading volume. The study concluded that there was a strong significant positive contemporaneous relationship between stock return and trading volume, mean while there was a significant negative contemporaneous relationship between stock return and past period trading volume.

El-Ansary and Atuea (2012), set to investigate the effect of stock trading volume on return in the Egyptian Stock Market. Using General Autoregressive Conditional Hetroskedasticity GARCH $(1,1)$ Model conducting this research we found that first, there is a positive correlation between trading volume (using both logarithm of turnover ratio and transactions number as measures of trading volume) and return, second, we found that there is a weak high significant contemporaneous relationship between trading volume using both measures and return which indicate that trading in the Egyptian security market is noise trading, and that

the Egyptian security market is informationally inefficient. Third, we found a negative lagged relationship using two and five days lag period between trading volume (using both measures) and return which means that increasing (decreasing) trading volume in the previous two and five days lead to decreasing (increasing) return and vice versa.

Yonis (2014), examined the causal relations among trading volume and returns between the US and Tiger economies stock markets. The study found a positive contemporaneous relationship between absolute return and trading volume in the New York and Tiger Economies stock markets using OLS and GMM estimator. Using MA-GARCH $(1,1)$ model, trading volume has a statistically significant positive effect on the conditional volatility of the markets, except South Korea. However, my finding also confirms that the GARCH effects are still statistically significant after considering trading volume in the variance equation. Moreover, the selected EGARCH models, after the inclusion of contemporaneous trading volume, attest the existence of a positive relationship between volatility and trading volume in the US and Tiger 
Economies stock markets. A VAR(2) model shows the existence of bi-causal relationship between return and trading volume in the Singapore market whereas, there is no scope for improving the predictability of returns by considering information flow in the form of trading volume on the US, Hong Kong, Korea and Taiwan stock markets.

Tehranchian Behravesh and Hadinia (2014), investigated a causality relationship between the trading volume and the stock returns using the data related to 220 member companies of Tehran Stock Exchange. According to the results obtained through the Philips - Perron Test, the said variables were integrated of order one. Also the Johansen's Co-Integration Test was used which revealed that there was a long run equilibration relationship between the stock returns and the trading volume. The findings of the Vector Error Correction Model confirmed a bidirectional causality and meaningful relationship between the said variables regarding which the level of effectiveness of the stock returns are more on the trading volume. That research demonstrated that although the trading volume and the stock return explain each others' changes, the mass behaviors were not approved psychologically in the above mentioned market. In other words increase in the stock returns increased the stock supply and demand more in comparison to the trading volume increasing the stock returns.

\subsection{RESEARCH METHODOLOGY}

The study used quantitative research design which involved the use of cross-sectional and longitudinal survey design. The financial information computed for each firm during the period of study was stacked into panels. This approach is useful for this kind of study where both the cross-sectional and longitudinal characteristics of the units being analyzed constitute an important ingredient of the study (Gujarati, 2003). The study used secondary data available from 2004 Jan to Dec 2016.

The target population of the study consisted of the sixty four companies listed in Nairobi securities exchange market that is, both financial and non-financial companies at the time. This population was taken due to the nature of companies listed in the NSE in that they have made their financial information public and represents all sectors of the economy. These companies are classified as: Agricultural companies, banking, commercial and communication services, automobiles and accessories, construction and allied, Energy and petroleum, Insurance and investment companies. Due to the small size of the study population, the researcher conducted a census of all the sixty four institutions listed in NSE. A census is done where all the firms in the target population are selected for analysis. This procedure was preferred to sampling as the small size of the population makes it possible to study all the firms in the population to be done and at the same time a census solves the accuracy problems associated with samples in representing the population. The study considered data on all companies listed in the exchange market for the period 2004 to 2016 and collected secondary data from all the firms listed in NSE that period.

Upon extracting data from the financial statements, quarterly statistical bulletins from CMA, and NSE hand books, Excel program was used to compute the ratios relevant for the study variables in each firm across time. Panel regression analysis using Eviews (Econometric package) was employed to establish how microstructure dynamics market returns of equity securities in Kenya. Finally, inferential statistics that included adjusted R-squared and t-test were used to determine the significance of the overall model and individual explanatory variables respectively. The results of the study were presented in form of tables.

\section{Variable measurement}

\section{Trading volume}

The market returns is dependent on Volume of trade which was determined by the logarithm of the number of shares traded at Nairobi securities exchange. This is the number of shares or 
contracts traded in a security or an entire market during a given period of time. This means that each time a person sells or buys shares of a stock, that is considered volume. Tallying of volume is done by the market exchanges and reported via major financial website.

\section{Model Specification}

Model specification involves coming up with a combination of study variables that represents the empirical relationship between the dependent, explanatory and moderating variables. This was done in line with the conceptual framework. The study employed panel regression model to analyze secondary data because the data was collected exhibited both time series and cross-sectional dimensions. The study used panel data to carry out the research analysis for 13 years starting from 2004 to 2016, panels are very important and increase precision as they contain detailed information as compared to cross sectional data and (Hoechle, 2007).Hsiao (2004),concluded that longitudinal data allow a researcher to analyze a number of important economic issues that can be addressed using cross sectional or time series data sets with ease. In Choi (2006) and Gujarati (2012) asserts that combinations of cross section observations, panel data will always provide better results with valuable information, with reduced collinearity among variables, more degrees of freedom and more efficiency.

Panel data does not only allow a researcher to construct and test more complicated behavioral models than purely cross sectional or time series data, but as suggested by Hsiao and Pesaran (2004),Random coefficient panel data models., panel data also provides a means of resolving or reducing the magnitude of a key econometrics problem that often arises in empirical studies. Gujarati (2012) has suggested various estimating techniques that can be used in estimation of the panel related models, that is pooled OLS, Random effect (RE), and Fixed Effect (FE). Stock, and Watson (2001), (Saikkonen,1992) and (Stock and Watson,1993) have proposed a simple approach termed Dynamic OLS (DOLS), to constructing an asymptotically efficient estimator that eliminates the feedback in the cointegrating system when $\mathrm{T} \rightarrow \infty$ and also $\mathrm{N} \rightarrow \infty$.

$\mathrm{MR}_{i t}=\beta_{0}+\beta_{4} T V_{i t}+\mu_{i t}+\varepsilon_{i t}$

Where:

Where MR is Market Returns of equities securities market, TV is the trading volume, $\mu_{i t}$ is the cross-sectional effect, $\varepsilon_{i t}$ is the error term $(\mathrm{j}=1,2, . ., 6) ; \beta_{i}$ Are the associated regression coefficients.

\subsection{RESULTS AND DISCUSSION}

\subsection{Descriptive statistics}

Table 1 presents the results on the variables descriptive statistics for the 50 companies out of the 64 listed companies. The reduction in the sample was attributed to cleanup of the data used the analysis. The cleanup was conducted to make sure that all the companies used do not have large missing observations. There was also the need to make sure that the companies include had traded for a reasonable amount of time to allow for a sensible analysis. These are the two major reasons the researcher arrived at a sample size of 50 companies out of 64 that were listed at the time the analysis commenced. It is always recommended to test the normality distribution of variables through the descriptive statistics before including them in further analysis such as the regression analysis. The key descriptive statistics presented above include; Mean, Median, Maximum, Minimum, Std. Dev., Skewness, Kurtosis.

\subsubsection{Market Return}

The first variable is the market Return. This variable was measure by the returns of each security in the market. The measures of central tendency used were mean, median, maximum and minimum value, standard deviation, skewness, kurtosis and Jarque-Bera (JB) test of normality (Table 1). Positive and low stock return's mean of $0.212622 \%$ is associates with less volatility (Table 1 ) of the series (consistent with low standard deviation; $10.19068 \%)$. The 
wide gap between maximum and minimum value (Maximum; 69.17544, Minimum; 55.56740 ) of stock return indicates that there is a high variability in stock return changes in the in Kenyan market. Stock return portrays a positive Skewness 0.689507 indicating a right tail of distribution which indicate that the data are fairly asymmetry. Kurtosis value was found to be
3.436973 which is $>3$, which shows that it is a leptokurtic distribution, sharper than a normal distribution, with values concentrated around the mean and thinner tails. Furthermore, significant JB value (5774.898) explains the deviation of normal distribution thus rejecting the null hypothesis these findings are in line with those of (Tapa and Hussin ,2016).

\section{Table 1 Descriptive statistics}

\begin{tabular}{lcc}
\hline Test statistic & Market returns $(\%)$ & Trading Volume (\%) \\
Mean & 0.212622 & 10.65393 \\
Median & $0.0000^{*} 00$ & 10.47771 \\
Maximum & 69.17544 & 19.70838 \\
Minimum & -55.56740 & 0.301030 \\
Std. Dev. & 10.19068 & 2.507377 \\
Skewness & 0.689507 & 0.179616 \\
Kurtosis & 7.436973 & 3.368802 \\
Jarque-Bera & 5774.898 & 70.90416 \\
Probability & 0.000000 & 0.000000 \\
Observations & 6420 & 6420 \\
\hline
\end{tabular}

\subsubsection{Trading volume}

This variable was measured by the number of shares traded. The measures of central tendency used were mean, median, maximum and minimum value, standard deviation, skewness, kurtosis and Jarque-Bera (JB) test of normality (Table 1). Positive and low trading volume mean of Mean Mean $10.65393 \%$ is associates with less volatility (Table 1) of the series (consistent with low standard deviation; 2.507377). The wide gap between maximum and minimum value (Maximum; 19.70838, Minimum; 0.301030) of trading volume indicates that there is a high variability in trading volume changes in the in Kenyan market. Trading volume portrays a positive Skewness 0.179616 indicating a right tail of distribution which indicate that the data are fairly asymmetry. Kurtosis value was found to be 3.368802 which is $>3$, which shows that it is a leptokurtic distribution, sharper than a normal distribution, with values concentrated around the mean and thinner tails.
Furthermore, significant JB value (70.90416) explains the deviation of normal distribution thus rejecting the null hypothesis these.

\subsection{Unit root Tests}

When it comes to variables with time series dimension (component) the unit root problem is of greater concern to the researcher than just descriptive statistic. Some of the panel unit roots that have taken center stage in literature are; These tests are; Levin, Lin and Chu t developed by (Levin, Lin and Chu ,2002), Breitung t-stat developed by (Breitung, 2000), Im, Pesaran and Shin W-stat developed by (Im, Pesaran and Shin, 2003), Fisher-type tests using augmented dickey fuller ADF and (Phillip and Peron) PP tests (Maddala and Wu ,1999) and Choi (2001). On the other hand (Hadri,2000) has developed another test which assumes the null of no unit root against the alternative of a unit root test. These tests therefore differs in terms of the assumptions made in their computations. This 
study conducted unit root test to assess the stationary of the variables used.

\subsubsection{Market returns of equity securities unit root}

Table 2 resents the unit roots tests of the dependent variable under three distinct techniques. This was done for comparison and for clarity purposes. The first set of two tested, test the unit root under the assumption that the variables have a common unit root process. The second set of three tested, test the unit root under the assumption that the variables have a individual unit root process.

Table 2: Market returns of equity securities: unit root

\begin{tabular}{|c|c|c|c|c|}
\hline Method & Statistic & Prob. & $\begin{array}{l}\text { Cross- } \\
\text { sections }\end{array}$ & Obs \\
\hline \multicolumn{5}{|c|}{ Null: Unit root (assumes common unit root process) } \\
\hline Levin, Lin and Chu t & -85.9524 & $0.0000^{*}$ & 50 & 6329 \\
\hline Breitung t-stat & -33.4667 & $0.0000^{*}$ & 50 & 6279 \\
\hline \multicolumn{5}{|c|}{ Null: Unit root (assumes individual unit root process) } \\
\hline Im, Pesaran and Shin W-stat & -72.9268 & $0.0000^{*}$ & 50 & 6329 \\
\hline ADF - Fisher Chi-square & 3030.51 & $0.0000^{*}$ & 50 & 6329 \\
\hline PP - Fisher Chi-square & 3484.93 & $0.0000^{*}$ & 50 & 6370 \\
\hline
\end{tabular}

${ }^{*}$ Means that is statistically significant at $95 \%$ confidence level

Table 2 resents the unit roots tests of the dependent variable (Market returns of equity securities). In particular the table presents the results of five basic tests of unit roots in panels. These tests are; Levin, Lin and Chu t developed by (Levin, Lin and Chu ,2002), Breitung t-stat developed by (Breitung, 2000), Im, Pesaran and Shin W-stat developed by (Im, Pesaran and Shin, 2003), Fisher-type tests using augmented dickey fuller ADF and (Phillip and Peron) PP tests (Maddala and Wu ,1999) and Choi (2001). From the test results the test statistics reveals that four of the test agree with the null hypothesis that the variable is stationary at level. The probabilities are very significant implying that we do reject the null hypothesis of a unit root problem apart from one of the test (Breitung tstat). The implication is that the variable is stationary. The results also shows that there were 50 categories considered (that is the number of companies included in the analysis).

\subsubsection{Trading volume unit root}

Table 3 resents the unit roots tests of the dependent variable under three distinct techniques. This was done for comparison and for clarity purposes. The first set of two tests, test the unit root under the assumption that the variables have a common unit root process. The second set of three tests, test the unit root under the assumption that the variables have a individual unit root process.

Table 3 resents the unit roots tests of the trading volume. In particular the table presents the results of five basic tests of unit roots in panels. These tests are; Levin, Lin and Chu t developed by (Levin, Lin and Chu ,2002), Breitung t-stat developed by (Breitung, 2000), Im, Pesaran and Shin W-stat developed by (Im, Pesaran and Shin, 2003), Fisher-type tests using augmented dickey fuller ADF and (Phillip and Peron) PP tests (Maddala and Wu,1999) and Choi (2001). From the test results the test statistics reveals that four of the test agree with the null hypothesis 
that the variable is stationary at level. The probabilities are very significant implying that we do reject the null hypothesis of a unit root problem apart from one of the test (Breitung t- stat). The implication is that the variable is weak stationary. The results also shows that there were 50 categories considered (that is the number of companies included in the analysis).

Table 3 Trading volume: unit root

\begin{tabular}{|c|c|c|c|c|}
\hline Method & Statistic & Prob. & $\begin{array}{l}\text { Cross- } \\
\text { sections }\end{array}$ & Obs \\
\hline \multicolumn{5}{|c|}{ Null: Unit root (assumes common unit root process) } \\
\hline Levin, Lin and Chu t & -10.2244 & $0.0000^{*}$ & 50 & 6238 \\
\hline Breitung t-stat & 0.11364 & 0.5452 & 50 & 6188 \\
\hline \multicolumn{5}{|c|}{ Null: Unit root (assumes individual unit root process) } \\
\hline Im, Pesaran and Shin W-stat & -14.6213 & $0.0000^{*}$ & 50 & 6238 \\
\hline ADF - Fisher Chi-square & 495.204 & $0.0000^{*}$ & 50 & 6238 \\
\hline PP - Fisher Chi-square & 1400.04 & $0.0000^{*}$ & 50 & 6370 \\
\hline
\end{tabular}

* Means that is statistically significant at $95 \%$ confidence level

\subsection{Correlation Test}

Table 4 presents the results on correlation analysis among the five study variables. In particular the correlations among Market returns and Trading Volume. The table also presents the results of probability levels.

Table 4 Correlation Test

\begin{tabular}{lll}
\hline Correlation & Market return & Trading Volume \\
\hline Market returns & 1.000000 & \\
Trading Volume & 0.028438 & 1.000000 \\
Probability & Market returns & Trading Volume \\
Market returns & ----- & ---- \\
Trading Volume & $0.0227^{*}$ & \\
\hline
\end{tabular}

${ }^{*}$ Means that is statistically significant at $95 \%$ confidence level

Table 4 presents the results on correlation analysis of the five variables. From the results the correlation analysis shows that there was high correlation between market returns and tading volume of 0.028438 and the associated $p$ value was statistically significant with a value of 0.0227 . This value shows that there was high level of correlation between the trading volume and market return variable.

\subsection{Panel Cointegration Tests}

Engle and Granger (1987) note that, cointegration test is based on an examination of the residuals of a spurious regression performed using I(1) variables. If the variables are cointegrated then the residuals should be integrated of order zero I(0). On the other hand if the variables are not cointegrated then the residuals will be integrated of order one I(1). In 
Mwiti Jedidah Karwitha et al., GJEBA, 2018; 3:12

this research even though the variables were found to be stationary from the unit root test it was decided to go into deeper analysis by executing the cointegration test. The testing was informed by the fact that the variables had a time series in panel structure.

The idea of cointegration is to assess whether there is some form of long run relationship among the variables under study. Table 5 presents the results of pedroni residual based cointegration test. This test was developed by Pedroni (1999; 2004). According to Pedroni
(1999; 2004), there are two alternative hypotheses: the homogenous alternative, for all (which Pedroni terms the within-dimension test or panel statistics test), and the heterogeneous alternative, for all (also referred to as the between-dimension or group statistics test). The general approach is to obtain residuals from the primary regression of the dependent variable on the independent variables. The next step was to regress the current values of the residuals on their lagged values and check whether there coefficients are less than unity or are unity.

\section{Table 5 Pedroni Residual Based Cointegration Test}

Pedroni Residual Cointegration Test, Series: Market Return Trading volume, Sample: 2004M01 2016M12, Included observations: 6420, Cross-sections included: 50, Null Hypothesis: No cointegration, Trend assumption: Deterministic intercept and trend, Automatic lag length selection based on SIC with a max lag of 12, Newey-West automatic bandwidth selection and Bartlett kernel

Alternative hypothesis: common AR coefs. (within-dimension)

\begin{tabular}{lcccc} 
& \multicolumn{3}{c}{ Weighted } \\
& $\underline{\text { Statistic }}$ & $\underline{\text { Prob. }}$ & $\underline{\text { Statistic }}$ & $\underline{\text { Prob. }}$ \\
Panel v-Statistic & 2.779979 & 0.0027 & -5.421184 & 1.0000 \\
Panel rho-Statistic & -160.1133 & 0.0000 & -161.0255 & 0.0000 \\
Panel PP-Statistic & -85.92791 & 0.0000 & -86.02405 & 0.0000 \\
Panel ADF-Statistic & -83.08972 & 0.0000 & -82.16147 & 0.0000
\end{tabular}

Alternative hypothesis: individual AR coefs. (between-dimension)

$\begin{array}{lcc} & \underline{\text { Statistic }} & \underline{\text { Prob. }} \\ \text { Group rho-Statistic } & -120.1355 & 0.0000 \\ \text { Group PP-Statistic } & -84.97284 & 0.0000 \\ \text { Group ADF-Statistic } & -82.11668 & 0.0000\end{array}$

${ }^{*}$ Means that is statistically significant at $95 \%$ confidence level

In total there are eleven test statistics presented in table 5. It was observed that they were all statistically significant as depicted by their respective $p$-values which were found to be highly statistically significant. The Panel vStatistic was 17.15682 and $p$-values was $0.0000^{*}$. The interpretation is that there was evidence of the long-run relationship among the variables since the probability of drawing a test statistic as extreme as the one observed, under the assumption that the errors are normally distributed, or that the estimated coefficients are asymptotically normally distributed was very low in all cases. The Panel v-Statistic Weighted was 3.869426 and $p$-values was $0.0001^{*}$. The interpretation is that there was evidence of the long-run relationship among the variables since the probability of drawing a test statistic as 
extreme as the one observed, under the This value clearly suggests that after adjusting assumption that the errors are normally for the degrees of freedom there is a relationship distributed, or that the estimated coefficients are asymptotically normally distributed was very low in all cases.

\subsection{Hypothesis Testing}

Trading volume has no significant effect on market returns of equity securities market in Kenya.

From table 6 the value of the R-squared 0.218491 and Adjusted R-squared 0.192709.

between Market risk and market returns of securities equity market. This indicates that Market risk causes a variation of $0.218491 \%$ on market returns of securities market. The value of F-statistic 8.474548 and Prob (F-statistic) $0.0000^{*}$ further confirms the relevance of market risk on market returns. The value of DurbinWatson statistic was found to be 2.128386 which is close to the value of 2.000000 which confirms that the model was identified.

\section{Table 6 Trading volume has no significant effect on market returns of equity securities market in Kenya.}

Dependent Variable: Market Return, Method: Panel Least Squares, Sample: 2004M01 2016M12, Periods included: 156, Cross-sections included: 50,Total panel (unbalanced) observations: 6420,Period weights (PCSE) standard errors and covariance (d.f. corrected)

$\begin{array}{ccccc}\text { Variable } & \text { Coefficient } & \text { Std. Error } & \text { t-Statistic } & \text { Prob. } \\ \text { Trading Volume } & 0.512438 & 0.100523 & 5.097732 & 0.0000^{*} \\ \text { C } & -5.246856 & 1.077042 & -4.871544 & 0.0000^{*}\end{array}$

Effects Specification

Cross-section fixed (dummy variables)

Period fixed (dummy variables)

$\begin{array}{llll}\text { R-squared } & 0.218491 & \text { Mean dependent var } & 0.212622 \\ \text { Adjusted R-squared } & 0.192709 & \text { S.D. dependent var } & 10.19068 \\ \text { S.E. of regression } & 9.156267 & \text { Akaike info criterion } & 7.298315 \\ \text { Sum squared resid } & 520964.5 & \text { Schwarz criterion } & 7.515455 \\ \text { Log likelihood } & -23221.59 & \text { Hannan-Quinn criter. } & 7.373465 \\ \text { F-statistic } & 8.474548 & \text { Durbin-Watson stat } & 2.128386 \\ \text { Prob(F-statistic) } & 0.0000^{*} & & \end{array}$

* Means that is statistically significant at $95 \%$ confidence level

\section{Trading Volume}

From table 6 , the regression coefficient of trading volume was found to be 0.512438 . This value shows that holding other variables in the model constant, an increase in trading volume by one unit causes the Market returns of equity securities to increase by 0.512438 percent. Tapa and Hussin (2016), conducted a 
regression analysis in Malaysian Market using OLS method. The study concluded that there is a strong significant positive contemporaneous relationship between stock return and trading volume. El-Ansary and Atuea (2012), set to investigate the effect of stock trading volume on return in the Egyptian Stock Market. Using General Autoregressive Conditional Hetroskedasticity GARCH $(1,1)$ Model to conducting their research they found that first, there was a positive correlation between trading volume (using both logarithm of turnover ratio and transactions number as measures of trading volume) and return, second, they found a negative lagged relationship using two and five days lag period between trading volume (using both measures) and return which meant that increasing (decreasing) trading volume in the previous two and five days lead to decreasing (increasing) return and vice versa. Yonis (2014), examine the causal relations among trading volume and returns between the US and Tiger economies stock markets. The study found a positive contemporaneous relationship between absolute return and trading volume in the New York and Tiger Economies stock markets using OLS and GMM estimator. The positive effect shows that there is a positive relationship between trading volume and market returns of securities market.

From table 6 , the conclusion was to reject the null hypothesis that the trading volume coefficient is zero, since the level of significant used was $5 \%$ and that the $p$-value observed was $0.0000^{*}=0 \%$ which was less than $5 \%$. These finding supports those of (Tapa and Hussin, 2016) who found trading volume to have a positive value at current period and a negative value at one lag after employing the VAR analysis. The interpretation was that trading volume causes the market returns of the securities market to increase. The listed companies should therefore consider the effect of trading volume on market returns of securities market.

\subsection{SUMMARY, RECOMMENDATION}

\subsection{Summary of findings}

The study established the effect trading volume on the market returns of equity securities market in Kenya. This involved investigating the effect of Trading volume on market returns of equity securities market in Kenya. The study revealed that all the two variables were cointegrated and thus a linear combination was possible and it was executed. The study focused on multidimentional diagnostic analysis, the descriptive statistics, unit root test, correlation analysis, and cointegration test. The study then proceeds to regression analysis. The regression techniques used was fixed and random effect. All these techniques were used in an effort to reveal the effect of trading volume on the market returns of equity securities market in Kenya.

\subsection{Conclusion}

The study sought to determine the effect of Trading volume on market returns of equity securities market in Kenya. The descriptive analysis revealed that trading volume was normally behaved since the kurtosis and skewness measurers were within the acceptable range of 0 and 3 respectively. The study also examined the unit root test statistics of Trading volume and found that the variable was stable at level. Unit root test was important to assess the stationary of Trading volume variable before including it in further analysis. The correlation analysis was also conducted to ascertain the orthogonality of market risk Trading volume and other variables in used in the study. The results revealed that the variable was not highly correlated with other variables. The regression model revealed that Trading volume has significant effect on market returns of equity securities market in Kenya. The study conclude that in Kenya the Trading volume has a positive and statistically significant effect on market returns of equity securities market in Kenya in Kenya. 


\subsection{Recommendation}

This research, has revealed that Trading volume has a significant effect on market returns of equity securities market in Kenya. The investors and other key market players should be keen on the variability of the Trading volume factor in the market. These key players should keep truck on the role of Trading volume on the market returns of both individual and all the stock in their portfolios. The study also recommends that the regulator, that is the CMA (Capital Market Authority) should be keen on enacting laws that enables disclosure of trading volume information on individual stocks in order to facilitate trade.

\subsection{Area for Further research}

This research was not able to identify all the possible variables with explanation power on market returns of equity market in Kenya. This is evidence from the regression results fixed, random effect model. The fixed and random model shows that the model was able to explain approximately R-squared $21.8491 \%$ on the variation of the equity market returns. It is therefore in this light that the future research should consider other variables which would increase the predictive power of the model. The other relevant variables would be variables such as the size of the firm, market value of the firm and the macroeconomic variables such as exchange rate, inflation, money supply among others.

\section{References}

1. Baltagi, B. H., Bratberg, E., and Holmås, T. H. (2005). A panel data study of physicians' labor supply: the case of Norway. Health Economics, 14(10), 1035-1045.

2. Breitung (2000), The Local Power of Some Unit Root Tests for Panel Data, Advances in Econometrics, Vol. 15: Nonstationary Panels, Panel Cointegration, and Dynamic Panels, Amsterdam: JAl Press, p. 161-178.

3. Chae, J., and Wang, A. (2003). Who makes markets? Do dealers provide or take liquidity. Unpublished working paper, Sloan School of Management, MIT.

4. Choi, I. (2001). Unit root tests for panel data. Journal of international money and Finance, 20(2), 249-272.

5. Choi, I. (2006). Combination unit root tests for cross-sectionally correlated panels. Econometric
Theory and Practice: Frontiers of Analysis and Applied Research: Essays in Honor of Peter CB Phillips. Cambridge University Press, Chapt, 11, 311-333.

6. Christie, W. G. (1994). Why do Nasdaq market makers avoid odd-eighth quotes? Journal of Finance , 49, 1813-1840.

7. Cooper, D. R., Schindler, P. S., and Sun, J. (2006). Business research methods (Vol. 9). New York: McGraw-Hill Irwin.

8. Easley, D., \& O'Hara, M. (2003). Microstructure and asset pricing. Handbook of the Economics of Finance, 1, 1021-1051.

9. Engle, R. F., and Granger, C. W. (1987). Cointegration and error correction: representation, estimation, and testing. Econometrica: journal of the Econometric Society, 251-276.

10. Fama, E. (1970). Efficient Capital Markets: A Review of Theory and Empirical work. Journal of Finance, 25, 383-417.

11. Gujarati, D. N. (2003). Basic Econometrics. London: McGraw Hill.

12. Gujarati, D. N. Sangeetha (2012), Basic Econometrics.

13. Hadri, K. (2000). Testing for stationarity in heterogeneous panel data. The Econometrics Journal, 3(2), 148-161.

14. Hoechle, D. (2007). Robust standard errors for panel regressions with cross-sectional dependence. Stata Journal, 7(3), 281.

15. Hsiao, C. (2004). Analysis of panel data (No. 54). Cambridge university press.

16. Im, K. S., Pesaran, M. H., \& Shin, Y. (2003). Testing for unit roots in heterogeneous panels. Journal of econometrics, 115(1), 53-74.

17. Karpoff, J. M. (1986). A theory of trading volume. The Journal of Finance, 41(5), 1069-1087.

18. Karpoff, J. M. (1986). A theory of trading volume. The Journal of Finance, 41(5), 1069-1087.

19. Kelley, E. K., and Tetlock, P. C. (2013). How wise are crowds? Insights from retail orders and stock returns. The Journal of Finance, 68(3), 12291265.

20. Kombo, D. K., and Tromp, D. L. (2010). Proposal and Thesis Writing. Pauline's Publication Africa.

21. Kothari, C. R. (2009). Research Methodology Methods and Techniques 2nd Revised Edition. Publishers. Nairobi: New Age International

22. Levin, A., Lin, C. F., and Chu, C. S. J. (2002). Unit root tests in panel data: asymptotic and finitesample properties. Journal of econometrics, 108(1), 1-24

23. Lim, K. P., \& Brooks, R. (2011). The evolution of stock market efficiency over time: a survey of the empirical literature. Journal of Economic Surveys, 25(1), 69-108.

24. Lim, K., and Brooks, R. (2011). The Evolution of Stock Market Efficiency over Time: A survey of the Empirical Literature. Journal of Economic Surveys , 25 (1), 69-108.

25. Maddala, G. S., and Wu, S. (1999). A comparative study of unit root tests with panel data and a new 
simple test. Oxford Bulletin of Economics and statistics, 61(S1), 631-652.

26. Mugenda, A. G. (2010). Social Science Research. Nairobi: Kijabe Printing Press.

27. Ngugi, R. W., and Njiru, R. (2005). Growth of the Nairobi Stock Exchange Primary Market.

Nairobi: Kenya Institute of Public Policy Research Analysis.

28. Pedroni, P. (1999). Critical Values for Cointegration Tests in Heterogeneous Panels with Multiple Regressors, Oxford Bulletin of Economics and Statistics, 61, 653-70.

29. Pedroni, P. (2004). Panel Cointegration; Asymptotic and Finite Sample Properties of Pooled Time Series Tests with an Application to the PPP Hypothesis, Econometric Theory, 20, 597-625.

30. Polit, D.F. and Hungler, B.P. 2013. Essentials of Nursing Research: Methods, Appraisal, and Utilization (8thedn). Philadelphia: Wolters Kluwer/Lippincott Williams and Wilkins.

31. Saikkonen, P. (1992). Estimation and testing of cointegrated systems by an autoregressive approximation. Econometric theory, 8(1), 1-27.

32. Sanjay Sehgal, Vibhuti and Vasishth, (2015). Past price changes, trading volume and prediction of portfolio returns: Evidence from select emerging markets. Journal of Advances in Management Research, Vol. 12 Issue: 3, pp.330-356, https://doi.org/10.1108/JAMR-10-2014-0056

33. Stock, J. H., and Watson, M. W. (1993). A simple estimator of cointegrating vectors in higher order integrated systems. Econometrica: Journal of the Econometric Society, 783-820.

34. Stock, J. H., and Watson, M. W. (2001). Vector autoregressions. Journal of Economic perspectives, 15(4), 101-115.

35. Tapa, A., and Hussin, M. (2016). The Relationship between Stock Return and Trading Volume in Malaysian ACE Market. International Journal of Economics and Financial Issues, 6(7S), 271-278.

36. Tehranchian, A. M., Behravesh, M., and Hadinia, S. (2014). On the Relationship between Stock Returns and Trading Volume: A Case Study. European Online Journal of Natural and Social Sciences, 3(3), pp-425.

37. Yen, G., \& Lee, C. F. (2008). Efficient market hypothesis $(\mathrm{EMH})$ : past, present and future. Review of Pacific Basin Financial Markets and Policies, 11(02), 305-329.

38. Yen, G., and Lee, C. F. (2008). Efficient market hypothesis (EMH): Past, Present and Future.

Review of Pacific Basin Financial Markets and Policies , 11, 305-329.

39. Yonis, M. (2014). Trading Volume and Stock Return: Empirical Evidence for Asian Tiger Economies. Masters thesis.

40. Akileng, G., Ogwang, A. A., \& Ssendyona, C. (2018). Determinants of market returns of securities exchanges in East Africa. Journal of Finance and Investment Analysis, 7(3), 1-3.

41. Hsiao, C., and Pesaran, M. H. (2004). Random coefficient panel data models.
42. Hui-Ching,S.H. (2014).The causal relationships between stock returns, trading volume, and volatility: Empirical evidence from Asian listed real estate companies, International Journal of Managerial Finance, Vol. 10 Issue: 2, pp.218-240, https://doi.org/10.1108/IJMF-10-2013-0103

43. Abdullahi,S.A. Kouhy,R. and Muhammad,Z. (2014).Trading volume and return relationship in the crude oil futures markets, Studies in Economics and Finance, Vol. 31 Issue: 4, pp.426438, https://doi.org/10.1108/SEF-08-2012-0092

44. Girard,E. and Omran,M. (2009).On the relationship between trading volume and stock price volatility in CASE, International Journal of Managerial Finance, Vol. 5 Issue: 1, pp.110-134, https://doi.org/10.1108/17439130910932369

45. Faff, R.W. and McKenzie,M.D. (2007).The relationship between implied volatility and autocorrelation, International Journal of Managerial Finance, Vol. 3 Issue: 2, pp.191-196, https://doi.org/10.1108/17439130710738736 